Bojana Crnogorac Stanišljević1, student doktorskih studija

Univerzitet u Novom Sadu, Filozofski fakultet
Primljen: 31.8.2020.

Prihvaćen: 23.4.2021.

PREGLEDNI NAUČNI RAD

UDC: $373.3: 81$ '243]: 373.3/.4

DOI: $10.19090 /$ ps.2021.1.52-63

\title{
ZNAČAJ UPOTREBE STRATEGIJA ZA UČENJE STRANOG JEZIKA NA NIVOU OSNOVNE ŠKOLE
}

\author{
Apstrakt
}

Ovaj rad nastoji da teorijski sagleda i istakne značaj strategija za učenje jezika, prvenstveno na početku učenja stranog jezika, kao i da pruži određene smernice za nastavnike. U savremenoj nastavi, strategije za učenje stranog jezika imaju važnu ulogu korisnog sredstva koje učenicima pomaže u učenju stranog jezika i u prevazilaženju prepreka sa kojima su sreću. Tako se u radu prvo navode definicije, klasifikacije i najvažnije karakteristike strategija za učenje stranog jezika, kao i njihov značaj i uloga u nastavi stranog jezika, što je potkrepljeno nizom raznih istraživanja. Upoznavanjem učenika osnovne škole sa što većim brojem strategija predstavlja zadatak od izuzetne važnosti za nastavnike te se zato naglašava delotvornost obuke strategijama za učenje. Zatim se razmatra najraniji uzrast na kojem je učenik sposoban da izveštava o primeni strategija. Dat je pregled najvažnijih istraživanja do sada, sa posebnim osvrtom na istraživanja u našoj zemlji. Naposletku su date pedagoške implikacije koje uključuju neophodnost istraživanja primene strategija za učenje stranog jezika na osnovnoškolskom uzrastu, kao i važnost osposobljavanja nastavnika koji treba da podučavaju učenike strategijama u svojim učionicama. Rad je podstaknut činjenicom da se dobre navike u učenju stranog jezika, koje uključuju primenu strategija za učenje, formiraju u najranijem dobu.

Ključne reči: strategije za učenje jezika, osnovna škola, strani jezik.

\section{Uvod}

Za život i rad u dvadeset prvom veku, koji karakterišu munjevite promene i velika količina podataka, neophodna su razna znanja i veštine. Stvaranje samosvesnog pojedinca koji uspeva da se prilagodi ovakvom okruženju počinje u osnovnoj školi. To je mesto na kojem se postavljaju čvrsti temelji znanja i veština. Isto tako, u osnovnoj

${ }^{1}$ bojana.crnogorac.stanisljevic@gmail.com 
školi se razvija odnos prema učenju stranog jezika, odnosno stvaraju se dobre navike u učenju koje učenicima mogu da budu veoma korisne u budućnosti. U skladu sa ovim, primena strategija za učenje stranog jezika predstavlja jednu takvu dobru naviku. Ove strategije pomažu učenicima da unaprede svoje znanje i da prevaziđu razne prepreke na koje nailaze prilikom učenja stranog jezika. Isto tako, primenjujući strategije, učenik preuzima odgovornost za svoje učenje i tako postaje samostalniji, što je u skladu sa isticanjem učenikove uloge u procesu učenja u savremenoj nastavi. Pojam strategija za učenje (engl. learning strategies) nije novijeg datuma, jer se naučnici njima bave već nekoliko decenija. Međutim, razvoj strateške kompetencije u nastavnoj praksi u našoj sredini je još uvek nedovoljno istražen, naročito na osnovnoškolskom uzrastu. Rezultati dveju studija sprovedenih kod nas na nivou osnovne škole pokazuju da upotreba strategija za učenje stranog jezika opada sa uzrastom učenika (Pilipović i Glušac, 2015, 2017). Autori navode da se stiče utisak da se strateška kompetencija nedovoljno razvija u višim razredima osnovne škole i otvaraju, između ostalog, pitanje obuke nastavnika za razvoj šireg spektra strategija za učenje (Pilipović i Glušac, 2017: 160161). Otuda potreba da se ukaže na njihov značaj.

\section{Strategije za učenje jezika}

Kognitivna teorija učenja je veoma doprinela da se strategije za učenje smatraju važnim činiocima u učenju stranog jezika. Ova teorija, koja se u velikoj meri oslanja na teoriju obrade informacija, predstavlja teorijsko uporište za strategije za učenje. Stoga, u skladu sa kognitivnom teorijom obrade informacija, strategije se definišu kao „posebne misli ili ponašanja koja pojednici koriste kako bi pomoću njih razumeli, naučili i zapamtili nove informacije" (O’Malley \& Chamot, 1990: 1). O'Mali i Šamoova (O’Malley \& Chamot, 1990) dalje navode i to da, kao i ostale složene kognitivne veštine, strategije mogu da prođu kroz tri faze učenja: kognitivnu, asocijativnu i autonomnu. Ovo dalje implicira da učenik u početku svesno koristi strategije, dok one ne pređu u autonomnu fazu, kada ih primenjuje automatski. Isto tako, Oksfordova (Oxford, 1990) navodi da strategije postaju automatske kada se dovoljno često koriste. Ova autorka daje svoju definiciju strategija za učenje stranog jezika navodeći da su to „određene radnje koje učenik preduzima kako bi olakšao učenje, ubrzao ga, učinio ga prijatnijim, samousmerenijim, efikasnijim i umeo da ga primeni u novim situacijama" (Oxford, 1990: 8). Pored navedenih definicija, postoji i niz drugih definicija strategija za učenje (Bialystok, 1978; Chamot, 1987; Chamot \& O’Malley, 1995; Cohen, 2003; O'Malley, Chamot, Stewner-Manzanares, Kupper \& Russo, 1985; Oxford, 1989; Rigney, 1978; Rubin, 1975; Stern, 1983; Weinstein i Mayer 1986). Prema Koenu (Cohen, 2003) strategije olakšavaju proces učenja jezika ukoliko učenici poseduju repertoar koji dobro funkcioniše i omogućavaju im da razvijaju sopstveni individualni pristup učenju. Radić-Bojanić (2013: 45) zaključuje da: (1) strategije za učenje odražavaju svestan napor koji učenik ulaže u učenje i usvajanje stranog jezika i omogućavaju 
učeniku da preuzme kontrolu nad procesom usvajanja; (2) strategije za učenje utiču na uspeh procesa usvajanja stranog jezika; (3) strategije za učenje su izvor individualnih razlika među učenicima; (4) strategije za učenje su karakteristike pojedinaca i smatra se da su veoma podložne promenama: one mogu da se nauče i da se vežbaju dok ne postanu automatizovane, tj. dok učenici ne postanu brzi i vešti u njihovoj upotrebi.

Postoji nekoliko klasifikacija strategija za učenje. Rubinova (Rubin, 1981) razlikuje dve vrste strategija za učenje: one koje direktno doprinose učenju i one koje indirektno doprinose učenju. Grupa autora (O’Malley, Chamot \& Küpper, 1989; O'Malley et al., 1985) ih svrstava u tri kategorije: kognitivne, metakognitivne i društveno-afektivne. Klasifikacija strategija Rebeke Oksford predstavlja najšire prihvaćenu i najdetaljniju klasifikaciju. Oksfordova (Oxford, 1990) svrstava strategije u dve osnovne grupe - direktne i indirektne strategije. Direktne strategije direktno pomažu učenicima da nauče ciljni jezik, odnosno doprinose učenju na direktan način i podrazumevaju neposredno bavljenje stranim jezikom. One uključuju tri podgrupe: kognitivne strategije, strategije pamćenja i kompenzatorne strategije. Kognitivne strategije uključuju različite vrste vežbanja, prijema i slanja poruka ili analize i zaključivanja, kao što su: ponavljanje, rekombinovanje, sumiranje, naglašavanje, deduktivno izvođenje zaključaka, prevođenje i sl. Strategije pamćenja služe efikasnijem pamćenju kroz stvaranje mentalnih veza, korišćenje slika i zvukova ili različite oblike obnavljanja znanja, što najčešće podrazumeva grupisanje pojmova, upotrebu semantičkih mapa i ključnih reči, stvaranje asocijacija i adekvatnog konteksta. Kompenzatorne strategije olakšavaju razumevanje i upotrebu stranog jezika uprkos nedostacima u znanju kroz pretpostavke o značenju nepoznatih jezičkih jedinica, upotrebu mimike, sinonima ili preoblikovanje poruke. Indirektne strategije na indirektan način utiču na učenje stranog jezika, odnosno pomažu učenicima da podrže i organizuju učenje jezika bez direktnog uključivanja u ciljni jezik i sastoje se od metakognitivnih, afektivnih i društvenih strategija. Metakognitivne strategije uključuju tehnike kojima se koordinira, prati, planira i procenjuje uspešnost sopstvenog učenja, kao što su: definisanje svrhe i cilja učenja i planiranih zadataka, stvaranje prilika za primenu stečenog znanja, utvrđivanje grešaka u sopstvenoj jezičkoj produkciji, reviziju i sl. Afektivne strategije obuhvataju kontrolu emocija, regulisanje anksioznosti i tehnike samoohrabrenja u procesu učenja i komunikacije na stranom jeziku kroz razgovor o emocijama koje prate učenje, smanjenje napetosti pomoću muzike i humora, samonagrađivanje za postignut uspeh ili vođenje dnevnika učenja. Društvene strategije uključuju postavljanje pitanja ili molbe za pojašnjenjem značenja u slučaju nerazumevanja, zatim saradnju s vršnjacima i govornicima s višim nivoom kompetencije, razvoj empatije i kulturne tolerancije i razumevanja (Oxford, 1990). Oksfordova (Oxford, 1990) navodi da je moguće da se kategorije strategija preklapaju i da njena taksonomija nije savršena, ali i to da je sveobuhvatna za njihovo razumevanje. Tako se njen upitnik Inventar strategija za učenje jezika (engl. Strategy Inventory for Language Learning) najčešće koristi kao instrument za procenu primene strategija. 
Veliki broj istraživanja posvećen je faktorima koji utiču na izbor i učestalost upotrebe strategija, kao što su pol, nacionalnost, nivo motivacije, uzrast, stil učenja, prethodno iskustvo, nivo znanja jezika, uverenja o učenju jezika, jezik koji se uči, vrsta zadatka, očekivanja nastavnika i drugo.

$\mathrm{Na}$ osnovu višedecenijskog proučavanja strategija za učenje jezika, istraživači dolaze do zaključka da učenici na svim nivoima obrazovanja koriste različite strategije u procesu učenja stranog jezika, da one uglavnom imaju pozitivan uticaj i stoga veoma važnu ulogu u procesu učenja stranog jezika. Strategije za učenje utiču na učenikovo postignuće (Bedell \& Oxford, 1996; Bialystok, 1981; Bremner, 1999; Cohen, 1998; O'Malley \& Chamot, 1990; Oxford \& Nyikos, 1989, i dr.) i čine učenje efikasnijim (Chamot, 1993; O'Malley \& Chamot, 1990; Oxford \& Crookall, 1989; Wenden \& Rubin, 1987, i dr.).

S obzirom na to da se upotreba strategija za učenje pokazala korisnom za učenje stranog jezika, neophodno je učenike upoznati sa što većim brojem strategija i podučiti ih kako i kada da ih primenjuju. Delotvornost obuke strategijama za učenje jezika predmet je mnogih istraživanja (Chamot, 2005; Chamot, Küpper, Impink-Hernandez, 1988; Chamot, Barnhardt, El-Dinary, Carbonaro \& Robbins, 1993; Graham \& Macaro, 2008; Nakatani, 2005; O’Malley \& Chamot, 1995; Wenden, 1987 i dr.). Koen (Cohen, 2011) smatra da eksplicitna obuka strategijama može da se primeni na svim nivoima, čak i kod dece predškolskog uzrasta.

\section{Strategije za učenje stranog jezika i učenici osnovne škole.}

Prema najsveobuhvatnijoj teoriji kognitivnog razvoja, Pijažeovoj teoriji (Piaget \& Inhelder, 1969), poslednji stadijum jeste stadijum formalnih operacija, počev od jedanaeste godine. Uzrast na kome se ovaj stadijum javlja može da varira u izvesnoj meri u zavisnosti od inteligencije deteta i okruženja. Ovaj stadijum je veoma važan jer dete sada ima sposobnost za apstraktno razmišljanje i poseduje metakogniciju, odnosno može da razmišlja o procesima svog mišljenja i učenja. Postoje studije koje pokazuju da se dečje metakognitivne sposobnosti razvijaju veoma brzo u ranim školskim danima. Prema Skotu (Scott, 2000, prema: Gu et al., 2005: 296), većina dece u jedanaestoj godini je potpuno sposobna da artikuliše svoja opažanja, mišljenja i uverenja.

Od detinjstva do zrelosti, s godinama i iskustvom, razvijaju se i poboljšavaju: veličina memorije ili brzina jednostavnih procesa pamćenja, strategije pamćenja, metakognicija i količina znanja koja olakšava učenje novih i povezanih informacija (Meadows, 1993, prema: Gu, Hu \& Zhang, 2005: 295-296). Iz tog razloga, uzimajući u obzir da su kognitivne i metakognitivne sposobnosti kod dece još uvek u fazi razvoja, njihov pristup učenju nije isti kao kod starijih učenika.

Za strateški razvoj je od presudnog značaja opšte prihvaćen stav da su deca na početku i u fazi formalnih operacija sposobna da prepoznaju i izveštavaju o primeni 
strategija. Tako su moguća istraživanja o primeni strategija i njihova obuka već na ranom uzrastu.

\section{Pregled rezultata dosadašnjih istraživanja}

Dosadašnja istraživanja pokazuju da učenici svih uzrasta primenjuju strategije za učenje stranog jezika. Proučavanjem literature jasno je da su istraživanja koja se bave primenom strategija kod učenika osnovne škole za sada malobrojna, kao i istraživanja koja se bave uticajem uzrasta na izbor strategija. Grupa autora smatra da su razlozi za to poteškoće pri sticanju uvida u repertoar strategija koje deca koriste i opšte predrasude da deca nemaju dovoljno razvijenu metakognitivnu svest kako bi razgovarali o procesima svog učenja (Gu et al., 2005).

Postoji nekoliko studija koja se bave strategijama kod mlađih učenika (Chamot \& El-dinary, 1999; Chesterfield \& Chesterfield, 1985; Doró \& Habók, 2013; Lan \& Oxford, 2003; Lee \& Oxford, 2008; Purdie \& Oliver, 1999 i dr.).

Tako su Česterfild i Česterfild (Chesterfield \& Chesterfield, 1985) proučavali bilingvalnu meksičko-američku decu. Rezultati istraživanja pokazuju da u predškolskom i u prvom razredu veliki procenat verbalnih interakcija na engleskom jeziku kod sve dece u uzorku uključuje strategije za učenje. Pokazalo se da postoji prirodan redosled u javljanju strategija za učenje jezika kako se dečje znanje stranog jezika proširivalo, ali i da postoje individualne razlike u brzini i u periodima u kojima su se određene strategije primenjivale. Deca sa naprednijim znanjem engleskog jezika primenjuju širi spektar strategija nego njihovi vršnjaci koji su manje napredni. Prve strategije koje su se koristile su receptivne, nezavisne strategije, kao što je ponavljanje i pamćenje, potom su usledile strategije povezane sa pokretanjem i održavanjem interakcije. Poslednje strategije koje su se razvile i koje su primećene samo kod nekoliko učenika na kraju prvog razreda su strategije koje pokazuju metakognitivno znanje, kao što je praćenje gramatičkih grešaka. Rezultati istraživanja nagoveštavaju da se iskustvo učenja jezika može organizovati na sistematičan način kako bi deca mogla da primenjuju strategije za učenje jezika na prirodan način. Autori preporučuju vežbanja rešavanja problema koja iziskuju primenu određenih strategija u cilju razvijanja strateške kompetencije.

Nadalje, Purdi i Oliver (Purdie \& Oliver, 1999) se bave strategijama za učenje jezika koje koriste bilingvalna deca (9-12) u australijskoj osnovnoj školi. Istraživanje se bavi odnosom između upotrebe strategija kod dece, njihovih uverenja o jezičkoj efikasnosti i njihovih stavova prema engleskom jeziku, što dalje naglašava važnost okruženja u razvoju strateškog pristupa učenju stranog jezika i u pozitivnom osećanju da budu uspešni učenici. Najviše su se primenjivale kognitivne strategije, prema široj klasifikaciji strategija koju navode O'Mali i saradnici (O'Malley et al., 1985), a najmanje društvene strategije.

Cilj jedne šestogodišnje studije je otkrivanje razlika između uspešnih i manje uspešnih učenika u primeni strategija za učenje. Ispitanici su bila deca uzrasta 
od predškolskog do šestog razreda u Sjedinjenim Američkim Državama u mešovitim okruženjima koji uče engleski kao drugi jezik (Chamot \& El-Dinary, 1999). Protokol razmišljanja naglas (engl. think-aloud protocol) koji je primenjen u istraživanju, pokazao se uspešnim. Uspešni učenici jezika su fleksibilniji kada koriste strategije i bolji u praćenju i zaključivanju nego manje uspešni učenici koji se drže jedne strategije. Zaključuje se da se manje uspešni učenici više usredsređuju na detalje, a uspešni na zadatak kao celinu. Mnoga deca, čak i neki prvaci, mogli su detaljno da opišu svoje procese razmišljanja i učenja, što pokazuje da metakognitivna svest počinje na prilično ranom uzrastu.

Lan i Oksfordova (Lan \& Oxford, 2003) sprovode istraživanje među tajvanskim učenicima šestog razreda koji uče engleski jezik kao strani. Učenici su popunjavali upitnik Inventar strategija za učenje jezika namenjen tajvanskoj deci koji je osmišljen na osnovu poznatog Upitnika Oksfordove (Oxford, 1990). Rezultati pokazuju da uspešniji učenici učestalije i efikasnije koriste širi spektar strategija višeg nivoa nego manje uspešni učenici. Najčešće primenjivane strategije su afektivne i kompenzatorne, a najređe strategije pamćenja.

Lan (Lan, 2005) sprovodi još jednu studiju u Tajvanu sa osnovcima koji uče engleski jezik kao strani u cilju pronalaženja odnosa između strategija za učenje jezika i faktora koji utiču na njihov izbor. Rezultati pokazuju da su dve metakognitivne strategije najučestalije strategije kod tajvanske dece, dok su najmanje korišćene strategije strategije pamćenja.

Grupa autora (Gu et al., 2005) sprovodi pilot istraživanje među singapurskom decom bilingvalima od prvog do četvrtog razreda. Rezultati studije pokazuju da deca koriste razne strategije u učenju engleskog jezika. Uspešna i manje uspešna deca koriste različite strategije. U istraživanju je korišćen protokol razmišljanja naglas sa prethodnom obukom i pokazalo se da ga je moguće koristiti sa mlađim učenicima osnovne škole bez obzira na težinu same procedure.

U studiji koja je sprovedena među mađarskim učenicima petog i šestog razreda osnovne škole u kontekstu učenja engleskog jezika kao stranog, najčešće primenjivane strategije kod obe grupe ispitanika su metakognitivne, a najređe kompenzatorne strategije (Doró \& Habók, 2013).

Rezultati istraživanja novijeg datuma među mladim učenicima (10-13 godina) i adolescentima (14-19 godina) koji uče engleski jezik u privatnim školama u Kambodži pokazuju da se više koriste kognitivne, metakognitivne i društvene strategije. Razlika između ove dve grupe ispitanika je u upotrebi kognitivnih i kompenzatornih strategija. Naime, mladi učenici više koriste ove stategije od adolescenata (Nhem, 2019).

Kostić-Bobanović i Ambrosi-Randić (2007) sprovode istraživanje u kojem hrvatski učenici osnovne škole najviše koriste metakognitivne strategije, a najmanje strategije pamćenja.

U našoj zemlji postoji veoma mali broj studija koje se bave strategijama za učenje stranog jezika na nivou osnovne škole. Pilipović i Glušac (2015) u svom istraživa- 
nju se bave strategijama za učenje engleskog jezika na nivou osnovne škole. Rezultati pokazuju da mlađi učenici (četrvrti razred) više upotrebljavaju strategije od starijih učenika (osmi razred), ali da se obe grupe ispitanika nalaze u grupi solidne upotrebe. Prema Oksfordovoj, prosečna vrednost iznad 3,5 je visoka, između 2,5 i 3,4 je solidna, a niža od 2,5 je slaba upotreba strategija. Obe grupe ispitanika najviše koriste metakognitivne strategije i to sa visokom upotrebom, a najmanje strategije pamćenja. Isti autori nakon dve godine sprovode drugu fazu istraživanja sa učenicima šestog razreda koji su u prvoj fazi pohađali četvrti razred. Rezultati istraživanja pokazuju pad u učestalosti upotrebe svih tipova strategija. Metakognitivne strategije su i dalje na prvom mestu, a strategije pamćenja se koriste najmanje (Pilipović \& Glušac, 2017).

Istraživanje sprovedeno na nivou osnovne škole koje sprovodi Crnogorac-Stanišljević (2019) bavi se kompenzatornim strategijama, jednom grupom direktnih strategija. Na početku istraživanja se utvrđuje repertoar svih strategija za učenje jezika kod učenika šestog, sedmog i osmog razreda koji uče engleski jezik kao strani. Najučestalije strategije su metakognitivne sa visokom učestalošću upotrebe, zatim slede društvene strategije u istoj grupi upotrebe. Najmanje upotrebljavane su afektivne strategije sa prosečnom vrednošću upotrebe koja je u grupi srednje učestalosti, na granici sa niskom učestalošću upotrebe. Sve strategije imaju srednju učestalost upotrebe. Kao i u prethodnom istraživanju, i ovde se koristio Upitnik Rebeke Oksford preveden na srpski jezik.

\section{Diskusija i pedagoške implikacije}

Kad se sagledaju dosadašnja istraživanja koja su se bavila upotrebom strategija za učenje stranog jezika kod učenika osnovne škole, može se zaključiti da učenici već na ranom uzrastu primenjuju strategije za učenje stranog jezika i da su, usled razvoja njihove metakognitivne svesti, sposobni da objasne proces svog učenja i razmišljanja. Utvrđeno je i da postoji redosled u javljanju strategija. Tako se vremenom primenjuju sve raznovrsnije i složenije strategije za učenje jer se znanje učenika proširuje. Vidljiva je i razlika u upotrebi strategija u zavisnosti od okruženja.

U navedenim istražAivanjima strategija za učenje stranog jezika sprovedenim u osnovnim školama u našem okruženju najviše se koriste metakognitivne strategije, što predstavlja neobičan rezultat s obzirom na to da ova grupa indirektnih strategija, kako sam naziv kaže, samo indirektno utiče na učenje stranog jezika i podržava ga. Stoga je od izuzetne važnosti da se u osnovnoj školi sprovede što više istraživanja koja bi utvrdila repertoar strategija za učenje stranog jezika kako bi se uporedili dobijeni rezultati i dodatno pojasnila upotreba pojedinih tipova strategija. Brojnim istraživanjima bi se utvrdilo trenutno stanje u učionicama stranog jezika koje bi predstavljalo polaznu osnovu za dalje planiranje odgovarajuće obuke učenika, odnosno stekao bi se uvid u stanje u našoj zemlji što se tiče strateške kompetencije učenika. 
Iako se Upitnik Oksfordove (Oxford, 1990) najčešće koristi za utvrđivanje repertoara strategija, nastavnicima je na raspolaganju i Anketa koju su osmislili Koen i Oksfordova (Cohen \& Oxford, 2002) pod nazivom Anketa o upotrebi strategija za učenje jezika za mlade učenike (engl. Young Learners' Language Strategy Use Survey). Ova anketa je zasnovana upravo na stavkama iz pomenutog Upitnika. Na osnovu ove ankete nastavnici stranog jezika će moći da razumeju dečji izbor strategija, što će im biti smernica za prilagođavanje svojih nastavnih metoda i unapređivanje nastave $u$ vidu uvođenja obuke onih strategija koje učenici najređe koriste, a koje su od izuzetne važnosti na tom nivou učenja stranog jezika. Važan preduslov za razvoj strateške kompetencije kod učenika jeste i osposobljavanje nastavnika stranog jezika za obuku strategijama za učenje.

\section{Zaključak}

Nakon višedecenijskog proučavanja strategija za učenje, one se smatraju činiocima koji mogu da doprinesu glavnom cilju učenja stranog jezika: razvijanju komunikativne kompetencije, pa tako razvoj strateške kompetencije učenika predstavlja važan cilj u savremenoj nastavi stranog jezika i počinje u osnovnoj školi. Cilj ovog rada bio je da ukaže na važnost primene strategija za učenje stranog jezika na nivou osnovne škole. Rezultati navedenih istraživanja su pokazali da je moguće utvrditi trenutni repertoar strategija za učenje stranog jezika na ranom uzrastu i da su učenici spremni da razgovaraju o primeni strategija. Isto tako, naglašava se vrednost uvida u primenu strategija u unapređivanju nastave i ukazuje se na potrebu osposobljavanja nastavnika za obuku strategijama. Posmatrano dugoročno, poznavanje i primena strategija može učenicima olakšati učenje stranog jezika, odnosno pomoću njih će naučiti kako da uče. Ovakva jedna korisna navika koja postaje automatizovana već na ranom uzrastu pomogla bi učenicima i izvan učionice, u stvarnim životnim situacijama. Isto tako, njihovom automatizacijom i postavljanjem čvrstih osnova smanjiće se broj problema prilikom učenja stranog jezika na višim nivoima obrazovanja. Uzimajući u obzir veliki značaj strategija za učenje stranog jezika, neophodno im je posvetiti mnogo više pažnje na osnovnom nivou obrazovanja, gde se nalazi njihov temelj.

\section{THE IMPORTANCE OF USING L2 LEARNING STRATEGIES ON THE PRIMARY SCHOOL LEVEL}

\section{Abstract}

This paper theoretically considers and emphasizes the importance of applying L2 learning strategies, primarily at the beginning of foreign language learning, as well as to provide certain guidelines for teachers. In contemporary teaching L2 learning 
strategies have an important role of a useful tool that helps students in foreign language learning and in solving problems that they encounter. Thus, the paper first lists the definitions, classifications and the most important characteristics of L2 learning strategies, as well as their importance and role in foreign language teaching, which is supported by various studies. Introducing primary school pupils to as many strategies as possible is a task of great importance for teachers and, therefore, this paper emphasizes the effectiveness of learning strategies instruction. The earliest age at which the pupil is able to report on the use of strategies is then considered. An overview of the most important research studies so far is given, with a special focus on the research in our country. Finally, pedagogical implications include the need for research of the application of L2 learning strategies at the primary school level, as well as the importance of training teachers who should teach pupils strategies in their classrooms. The paper is motivated by the fact that good habits in L2 learning, which include the use of L2 learning strategies, are formed at the earliest age.

Key words: language learning strategies, primary school, foreign language.

\section{Literatura}

Bedell, D. and Oxford, R. L. (1996). Cross Cultural Comparison of Language Learning Strategies in the People's Republic Of China and Other Countries. In Rebecca Oxford (Ed), Language Learning Strategies Around the World: Cross-Cultural Perspective. Honolulu: University of Hawaii.

Bialystok, E. (1978). A theoretical model of second language learning. Language Learning, Vol. 28, No.1, 69-83.

Bialystok, E. (1981). The Role of Conscious Strategies in Second Language Proficiency. Modern Language Journal, 65 (1), 24-35.

Bremner S. (1999). Language learning strategies and language proficiency: Investigating the relationship in Hong Kong. Canadian Modern Language Review/La RevueCanadienne des Langues Vivantes, 55, 490-514.

Chamot, A. U. (1987). The Learning Strategies of ESL Students. In A. Wenden \& Joan Rubin (eds), 71-83.

Chamot, A. U. (1993). Student responses to learning strategy instruction in the foreign language classroom. Foreign English Annals, 26, 308-321.

Chamot, A. U. (2005). Language learning strategy instruction: Current issues and research. Annual Review of Applied Linguistics, 25, 112-30.

Chamot, A.U., Barnhardt, S., El-Dinary, P.B., Carbonaro, G. \& Robbins, J. (1993) Methods of Teaching Learning Strategies in Foreign Language Classrooms. National Foreign Language Resource Center, Georgetown University/Center for Applied Linguistics, Washington, D.C. 
Chamot, A. U. and El-Dinary, P. B. (1999) Children's learning strategies in language immersion classrooms. Modern Language Journal, 83, 319-38.

Chamot, A. U.; Küpper, L; Impink-Hernandez, M. V. (1988). A study of learning strategies in foreign language instruction: first year report, Mclean, Va. Interstate Research Associates.

Chamot, A. U. \& O'Malley, J. M. (1994). The CALLA handbook: Implementing the Cognitive Academic Language Learning Approach. Reading, MA: Addison Wesley.

Chesterfield, R. and Chesterfield, K.B. (1985). Natural order in children's use of second languagelearning strategies. Applied Linguistics, 6, 45-59. Preuzeto 02.04.2020. sa:http://citeseerx.ist.psu.edu/viewdoc/download?doi=10.1.1.881.4977\&re$\mathrm{p}=\mathrm{rep} 1 \&$ type $=\mathrm{pdf}$

Cohen, A. (2003). The learner's side of foreign language learning: Where do styles, strategies, and tasks meet? IRAL, 41, 279-291.

Cohen, A. D. (2011). Strategies in Learning and Using a Second Language ( $2^{\text {nd }}$ ed.). London and New York: Routledge.

Cohen, A. D. and Oxford, R. L. (2006). Young Learners' Language Strategy Use Survey. In Cohen, A. D. and Weaver, S. J. (Eds.), Styles and Strategies-Based Instruction: A Teachers 'Guide. Minneapolis, MN: Center for Advanced Research on Language Acquisition, University of Minnesota.

Crnogorac Stanišljević, B. (2019). Upotreba kompenzatornih strategija za učenje u nastavi engleskog jezika na nivou osnovne škole. Pedagoška stvarnost, 65, (2), 186-198.

Doró, K. \& Habók, A. (2013). Language Learning Strategies in Elementary School: The Effect of Age and Gender in an EFL Context. JLLT, Volume 4, Issue 2, 25-37. Preuzeto 01.05.2020.sa:https://pdfs.semanticscholar.org/229e/411debe4798b13a3a6601286a8890911dfb4.pdf

Graham, S. and Macaro, E. (2008) Strategy instruction in listening for low-intermediate learners of French. Language Learning, 58(4), 747-83.

$\mathrm{Gu}$, P. Y., Hu, G. and Zhang, L. J. (2005). Investigating Language Learner Strategies among Lower Primary School Pupils in Singapore. LANGUAGE AND EDUCATION, Vol. 19, No. 4, 281-303. Preuzeto 05.05.2020. sa: https://www.researchgate.net/profile/Guangwei_Hu/publication/234119405 Investigating_Language_Learner_Strategies_among_Lower_Primary_School_Pupils_in_Singapore/ links/5b91d5124585153a53001f1a/Investigating-Language-Learner-Strategies-among-Lower-Primary-School-Pupils-in-Singapore.pdf

Kostić-Bobanović, M. \& Ambrosi-Randić, N.(2008). Language learning strategies in different English as a foreign language education levels. DRUŠ. ISTRAŽ. ZAGREB, br. 1-2, 281-300. Preuzeto 12.06.2020. sa: https://hrcak.srce.hr/22757

Lan, R. L. (2005). Language learning strategies profiles of EFL elementary school students in Taiwan. University of Maryland, doctoral dissertation. 
Lan, L. R. \& Oxford, R. L. (2003). Language learning strategy profiles of elementary school students in Taiwan. International Review of AppliedLinguistics in Language Teaching, 41(4): 339-379.

Lee, K.R. \& Oxford, R. (2008). Understanding EFL learners'strategy use and strategy awareness. Asian EFL Journal, 10 (1), 7-32.

Nakatani, Y. (2005) The effects of awareness-raising training on oral communication strategy use. Modern Language Journal, 89(1), 76-91.

Nhem, D. (2019). Language Learning Strategies: A Comparative Study of Young and Adolescent Cambodian Learners. International Journal of Language and Literary Studies, Volume 1, Issue 2, 34-45. Preuzeto 15.06.2020. https://papers. ssrn.com/sol3/papers.cfm?abstract id $=3447602$

O’Malley, J. M. and Chamot, A. U. (1990). Learning Strategies in Second Language Acquisition. UK: Cambridge University Press.

O'Malley, J.M. and Chamot, A.U. (1995). Learning strategies in second language acquisition. Cambridge: Cambridge University Press.

O’Malley, J. M., Chamot, A. U. \& Küpper, L. (1989). Listening Comprehension Strategies in Second Language Acquisition. Applied Linguistics, Volume 10, Issue 4, 418-437.

O’Malley, J. M., Chamot, A. U., Stewner-Manzanares, G., Kupper, L. \& Russo, R. P. (1985). Learning strategies used by beginning and intermediate ESL students, Language Learning, 35/1, 21-46.

Oxford, R. L. \& Crookall, D. (1989). Research on language learning strategies: Methods, findings, and instructional issues. Modern Language Journal, 73, 404419.

Oxford, R. L. (1989). 'The Best and the worst': an exercise to tap perceptions of language-learning experiences and strategies, Foreign Language Annals, 22/5, 447454.

Oxford, R. L. (1990). Language learning strategies: What every teacher should know. New York: Newbury House.

Oxford, R. L., \& Nyikos, M. (1989). Variables affecting choices of language learning by university students. Modern Language Journal, 73(3), 291-300.

Piaget, J. \& Inhelder, B. (1969). The Psychology of the Child. New York: Basic Books.

Pilipović, V. \& Glušac, T. (2015). Uzrast kao faktor u izboru strategija učenja engleskog jezika u osnovnoj školi. Nastava i vaspitanje, vol. 64, br. 2, 343-356.

Pilipović, V. \& Glušac, T. (2017). „Kritični period” u izboru strategija za učenje stranog jezika. Zbornik radova Filozofskog fakulteta u Prištini, XLVII(1)/2017, 149-167.

Purdie, N. and Oliver, R. (1999) Language learning strategies used by bilingual school-aged children. System 27, 375-88.

Radić-Bojanić, B. (2013). Strategije za razumevanje metaforičkog vokabulara. Novi Sad: Filozofski fakultet. 
Rigney, J.W. (1978). Learning strategies: A theoretical perspective. In H. F. O’Neil (Jr) (ed), 165-205.

Rubin, J. (1975). What the good language learner can teach us. TESOL Quarterly, 9 (1), 41-51.

Rubin, J. (1981). Study of cognitive processes in second language learning, Applied Linguistics, 11, 117-131.

Stern, H. H. (1983). Fundamental Concepts of Language Teaching. Oxford: Oxford University Press.

Weinstein, C. E. \& Mayer, R. E. (1986). The teaching of learning strategies. In M. Wittrock (Ed.), Handbook of research on teaching (3rd ed., pp. 315-327).

Wenden, A. (1987). Incorporating learner training in the classroom. In Wenden, A.; Rubin, J., Learner Strategies in Language Learning, Englewood Cliffs, N.J., Prentice Hall.

Wenden, A. L. \& Rubin, J. (Eds.). (1987). Learner strategies in language learning. Englewood Cliffs, NJ: Prentice Hall. 